\title{
Implementation and Impact of Internal Control in Preventing Fraud in The Public Sector
}

\author{
Astri Karina Murti ${ }^{1}$. Teguh Kurniawan ${ }^{2}$ \\ \{astri.k.murti@gmail.com¹. teguh.kurniawan@ui.ac.id² \\ University of Indonesia, Indonesia ${ }^{1}$. University of Indonesia, Indonesia ${ }^{2}$
}

\begin{abstract}
Fraud is a growing problem and can cause extraordinary threats to the organization. Failure to prevent and detect fraud has serious consequences for the organization. This study discusses how internal control in the public sector can prevent fraud. To achieve these goals, researchers use a literature study of various publications related to internal control in the public sector. The results showed that the weaknesses of internal control have been identified to cause fraud. Fraud will never be prevented completely, so that public sector organizations can implement internal controls to prevent and detect fraud. Management in the public sector must be able to create awareness and understanding of anti-fraud culture to all elements in the organization as an effort to prevent fraud.
\end{abstract}

Keywords: Internal control, Fraud, Prevention, Implementation, Public sector

\section{Introduction}

Fraud is an increasingly growing problem and raise an extraordinary threat to organizations. Fraud is a significant problem in many organizations due to its greater impact on the economy and reputation [1]. The Association of Certified Fraud Examiners (ACFE) Global [2] explains that fraud is a set of intentional actions with the intention of gaining personal benefits from manipulation of financial statements, corruption, asset misappropriations and other resources. Various kinds of fraud faced by the organization, among them are occupational fraud, corruption, and financial statement fraud [3]. Fraud is difficult to avoid in organizations [4] [5] [6], especially in the public sector [7].

Failure to prevent and detect fraud has serious consequences for the organization. Fraud can occur in the public and private sectors [8]. The public sector has unique characteristics compared to private organizations [9]. One that is illustrated is public services in the area of financial and budget management. The public sector ensures the achievement of the Government's goal of working to improve the welfare of the community. The Government implements internal controls because the relationship between the Central Government and Regional Government is complex [10]. Internal control is not limited to the organization's plan, but also the decision-making process that leads to the supervisor's authorization for certain transactions. Local Government's dependence on the Central Government in terms of financial balance control mechanisms takes place less effectively so that an internal control system is needed in monitoring, evaluating, and increasing the effectiveness of internal control [11] [12] [13]. 
A survey conducted by ACFE Indonesia [2] revealed that the most common fraud in Indonesia is corruption. Corruption is mostly done by public organizations, which is the most harmful fraud in Indonesia.

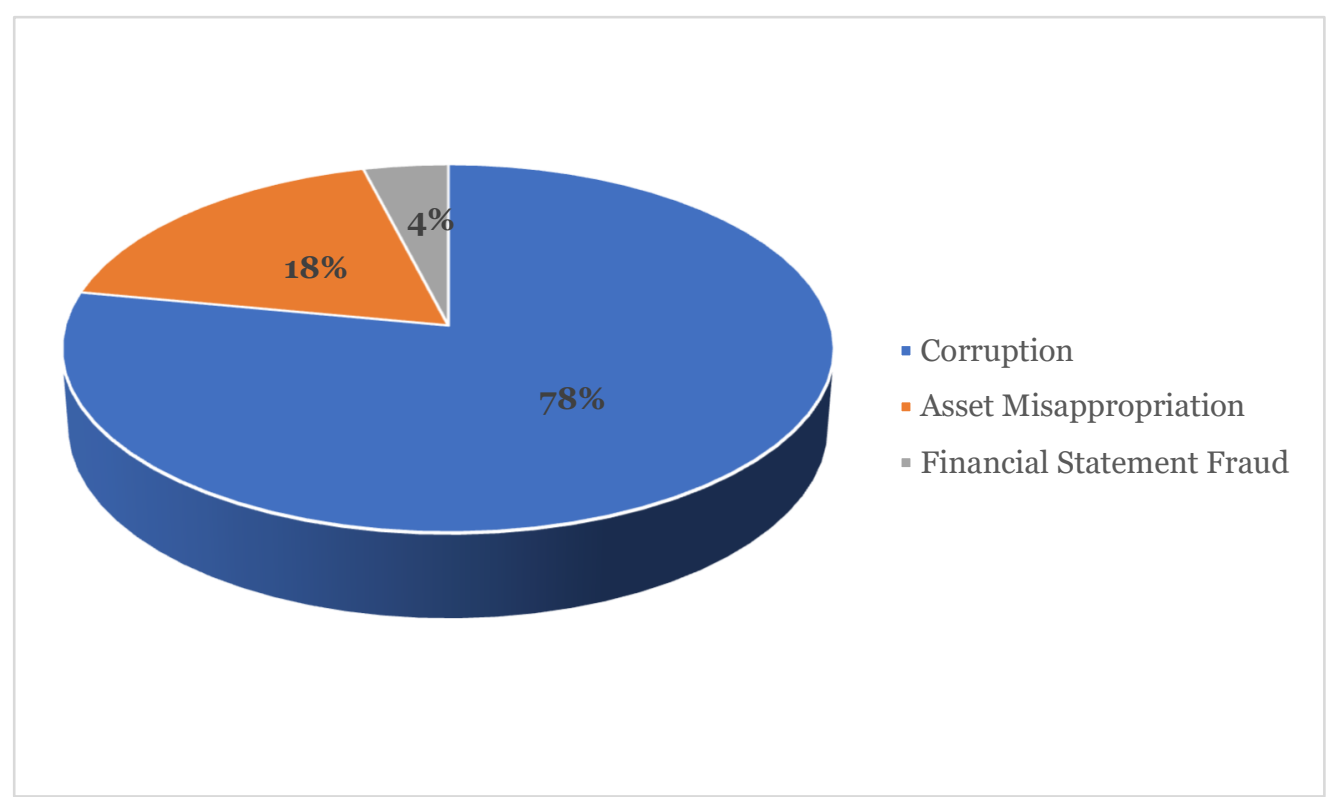

Figure 1 [2] The most harmful fraud in Indonesia

ACFE Indonesia's research results [2] show that every year an average of $5 \%$ of the organization's income becomes a victim of fraud. If the estimated loss value of 5\% is applied to the national economy, namely the Gross Domestic Product or the APBN volume, both on the revenue and expenditure side plus the APBD, the magnitude of the impact of fraud can be imagined. The larger the scale of an organization's income, the greater the potential loss value.

Based on data from the Komisi Pemberantasan Korupsi (KPK) [14], during 2016-2018 there were 313 cases of corruption that occurred in several government institutions in Indonesia. Cases that occurred included fraud on the project budget, corruption in the procurement of goods and services, and bribery of licensing. 


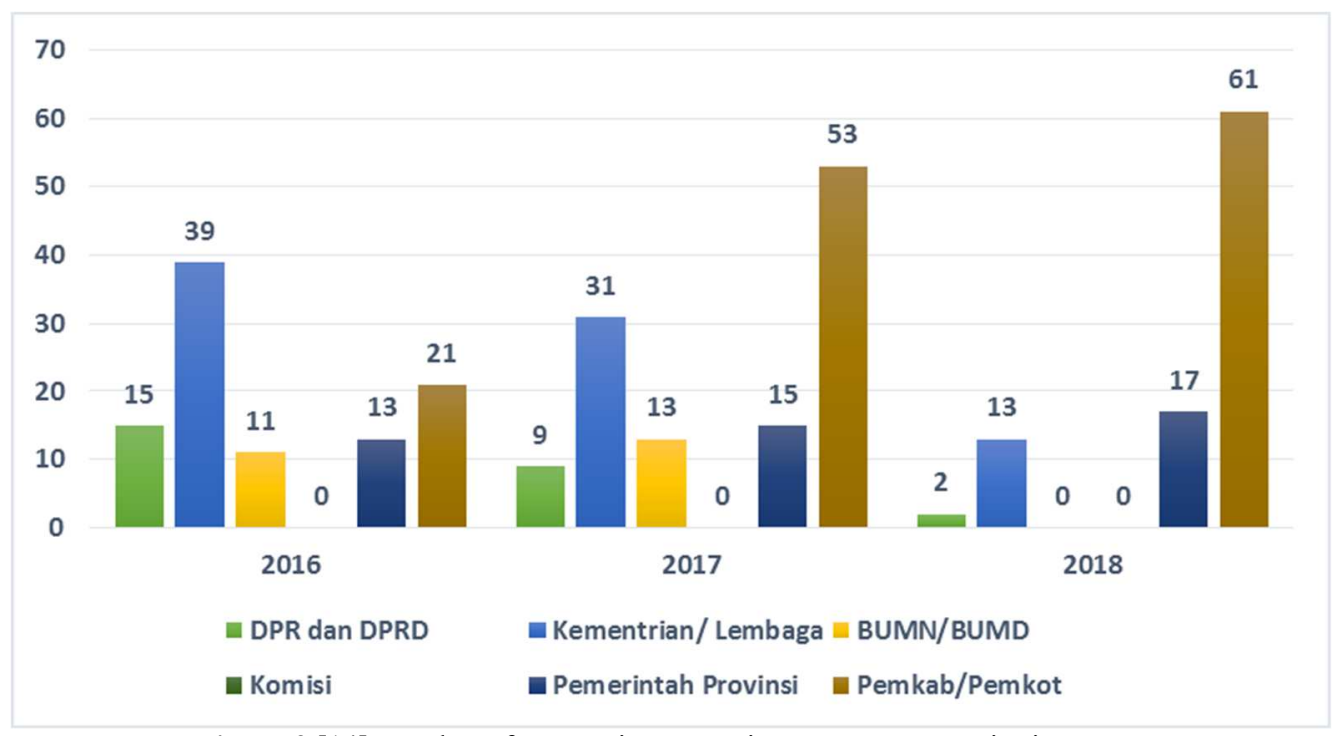

Figure 2 [14] Number of Corruption Cases in Government Institutions

The cause of fraud according to KPMG Fraud, Bribery, and Corruption Survey 2013 conducted in Australia and New Zealand in 2012 was weak internal control [8]. Scott Green explains that internal control is an important component of the overall management process [15]. Thus, the implementation of an internal control system is very important to reduce and even prevent fraud.

Internal control is part of the management system which is generally considered to be the main deterrent to fraud [15]. Internal control is a process that is influenced by the board of directors, management, and other personnel designed to provide adequate confidence in the achievement of objectives in the effectiveness and efficiency of operations, reliability of financial statements and compliance with applicable laws and regulations [16]. ACFE classifies forms of fraud into 3 (three), such as financial statements fraud, asset misappropriation, and corruption. Asset misappropriation and financial statements fraud are common in private organizations, while corruption is common in the public sector [3]. Internal control weaknesses in the presentation of financial statements, cash management, fixed asset management, and revenue management [9], can cause fraud [17]. If management is not good in implementing internal controls, it is certainly that the space for conducting fraud is widely open in a very subtle way [17].

Basically, internal control aims to identify the occurrence of fraud in the implementation of activities from a predetermined plan, so that corrective actions can be taken by management [18]. Internal control is built to achieve organizational goals by utilizing all things economically, efficiently, effectively, and in accordance with applicable regulations [18]. However, inherent limitations in internal control cannot be avoided [17]. Human error and deliberate fraud are factors that are usually considered when implementing internal control [17]. Inadequate internal control will provide opportunities for employees to commit fraud [19].

Weaknesses in internal control have been identified to result in fraud [17]. Internal control weaknesses provide extensive fraud opportunities making it easier for fraud perpetrators to commit fraud. Internal control systems need to be developed, continuously improved so that the detection of fraud in reporting gets actual results [20]. Based on this background, this article 
reviews the implementation and aspects of internal control that have an influence on fraud prevention in public organizations. It is very important that public organizations understand the underlying causes of fraud, the types of fraud, the implementation that is carried out in preventing fraud, and the impact of controls carried out in preventing fraud. Articles on internal control in fraud prevention are slightly, therefore this article expected to provide an understanding that strong internal control can prevent fraud and the tendency of individuals to commit fraud is not contained in the elements of internal control.

\section{Method}

The study discusses how internal control in the public sector can prevent fraud. To achieve this goal the researchers used the method of collecting literature study data (literature review) of various publications, reports, and news related to internal control in the public sector. Literature study is carried out with the hope that researchers can get theories and thoughts relevant to internal control issues in preventing fraud that occurs in the public sector. Thus, this research can be used as a reference in analyzing how internal control is implemented so that the public sector can successfully prevent fraud and achieve desired goals.

\section{Results and Discussions}

\subsection{Implementation of Internal Control}

Good organizational culture and effective internal control are very important for the public sector. The public sector cannot fully trust management and employees within an organization to do the right thing [15]. Internal control, according to COSO, is a process involving the board of commissioners, management, and other individuals designed to provide confidence regarding the achievement of operational effectiveness and efficiency, financial reporting reliability, and compliance with applicable laws and regulations. Internal control systems include policies and procedures designed to provide certainty for management so that organizational goals and objectives are achieved [16]. Stakeholders in the public sector act an important role in implementing effective and efficient internal controls, and making internal controls function [21]. Stakeholders must have a broad understanding of the need for an effective internal control system and support the objectives of internal control as part of achieving organizational goals [16]. 
Internal control is a tool used by fund management to directly relate to organizational goals. Implementation of internal control requires management that significantly provides intensive communication to personnel within the organization. Management is an important element in internal control. However, all personnel in the organization still act an important role in realizing internal control objectives that are in line with organizational goals [21].

Internal control has three important functions [22], such as:

a. Preventive Control. Internal control as preventive is designed to avoid events or problems.

b. Detective Control. Detective internal controls are designed to identify problems after they occur.

c. Corrective Control. Corrective internal control is an action to solve the problem found by the control for inspection.

It is important in fraud prevention by establishing an appropriate internal control system and separating the functions and responsibilities of work units appropriately [23]. Meanwhile, according to COSO, fraud prevention is carried out by carrying out checks and balances on a routine document done by public sector organizations [16]. Effective internal control is obtained by hiring competent personnel to effectively control physical access to assets. facilities. and information [22]. Research from ACFE found that fraud prevention can be done by taking the basic steps of training employees about fraud prevention so that the organization can ensure employees in the organization knowing the basic techniques of fraud prevention, communicate regularly with employees about anti-fraud policies, how to report suspicions of violations, and the potential consequences of fraud behavior [2]. Moreover, the organization can also be proactive in applying the code of ethics for management and employees.

\subsection{Fraud Prevention}

Fraud are actions that can pose extraordinary threats to organizations throughout the world. The Institute of Internal Auditors [24] said that fraud is an unnatural and illegal act that is intentionally done to cheat of the various types of fraud faced by organizations, fraud committed by officials and employees in the organization is a threat within the organization. According to Albrecht et al [25], there are no definite rules that can be set in defining fraud. because fraud includes surprising ways, tricks, injustices committed to deceiving others or other parties. Fraud involves all the ways in which individuals benefit above others by falsifying [25].

ACFE Global defines fraud as a set of intentional actions with the intention of gaining personal benefits from the manipulation of financial statements, corruption, asset misappropriations, and other resources [3]. Meanwhile, David Coderre [26] describes fraud as an act of deviation that is marked by the intention to deceive and obtain benefits for yourself. According to Cressey [27], fraud can be explained by using the Fraud Triangle theory. This theory explains that the cause of fraud is due to pressure, opportunities, and rationalizations. 


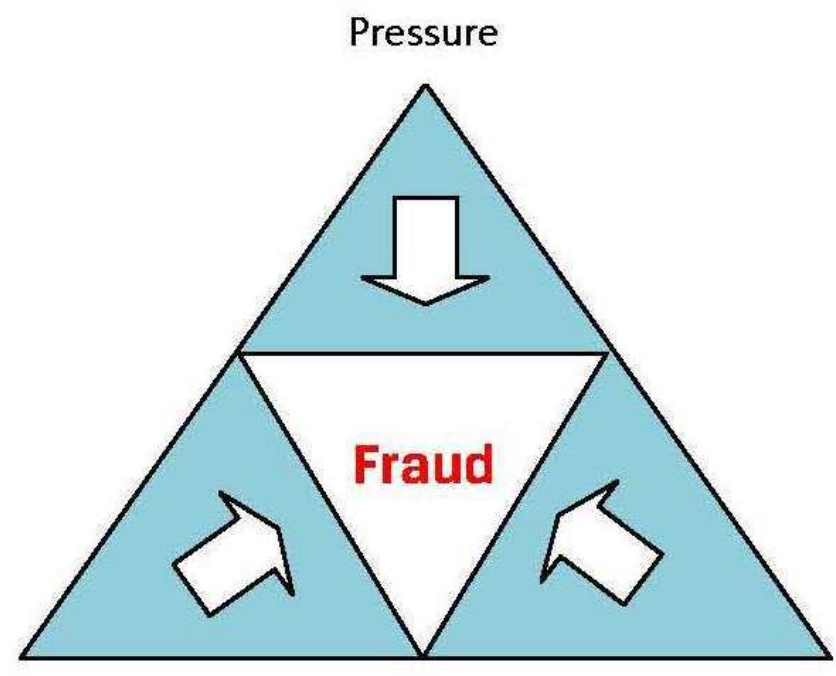

Opportunity

Rationalization

Figure 3 [27] Fraud Triangle Theory

The first element is pressure to force someone to commit fraud which came from internal and external perpetrators, for example financial pressure and employee's pressure. There are 4 (four) types of pressure, such as financial pressures, vices, work-related pressures and other pressures [25]. Pressure that causes a person to be at a stress level is usually financial [17]. An employee may have pressure to support his lifestyle while earning a low income.

When an employee feels opportunities to commit fraud, then fraud occurs. Opportunities make people motivated to commit fraud because of internal control weaknesses. When fraudsters know there are weaknesses in internal control, the situation provides an opportunity for an employee to commit fraud [28]. For example, the organization's effectiveness in recording assets can provide an opportunity for an employee to be able to misuse assets.

The third element is rationalization. Rationalization is a situation where a fraudster seeks justification for what he did was right or allowed. Fraud done by the perpetrator is a normal thing for other people to do. For example, an employee uses company assets for personal purposes which he feels are permissible because another employee is doing the same thing. Similar to the Fraud Triangle put forward by Donald R. Cressey [27], Steve Albrecht of Brigham Young University in 1980 studied and analyzed fraud. Albrecht explained about the motivation to commit fraud into the Fraud Scale. The results of his research show that people who are most likely to commit fraud at work have lifestyles beyond their means, have personal debt, desire to have social status, and pressure in the family and even peers. Employees who feel underpaid and underappreciated tend to commit fraud. The desire to buy gifts for friends or family can be called a motivator. However, employees will not commit fraud even though there are situational needs and have opportunities. Motivation to commit fraud depends on how strong the opportunity, motivation, and rationalization affect each situation [25]. The results of fraud research are known to the facts of fraud perpetrators as follows:

a. All levels of education are perpetrators of fraud. Fraud is not only done by people which have a lower educational background, but also by people in higher educational background. 
b. The longer people work in an organization, the greater the risk of fraud.

c. Increasing age accompanied by improvement in position or education, the capability to commit fraud also increases.

Public sector organizations are not immune to fraud [29]. Management within the organization is the main responsibility for fraud prevention. An understanding of how opportunities, pressures, and rationalization contribute to fraud can help management recognize which areas are vulnerable to fraud so that management can strengthen areas that are vulnerable to fraud [25]. Limited resources, operational complexity, and continuous change are challenges that must be faced by public sector organizations to implement adequate preventive controls in preventing fraud [29]. The COSO framework highlights several focus points that must be considered in preventing fraud, such as:

a. Consider various types of fraud by considering fraud reporting, possible loss of assets, and corruption resulting from various ways in which fraud and violations occur.

b. Value of incentives and pressures by considering the risk assessment related to incentives and pressures to commit fraud.

c. Assess opportunities by considering risk assessments related to opportunities for the acquisition, use or disposal of unauthorized assets.

d. Assess attitudes and rationalization by considering how management and other personnel might be involved in justifying fraud.

Fraud prevention is carried out to control the factors driving the emergence of fraud by creating conditions that facilitate detection of encouraging fraud prevention [30]. Fraud is a serious threat to the organization so it must be prevented as early as possible. Public sector organizations must realize that the potential for fraud can occur from within and outside the organization. The fraud prevention methods commonly used by management in accordance with Badan Pengawasan Keuangan dan Pembangunan (BPKP) [31] are:

a. Determination of anti-fraud policy. Working units that make policies must have high integrity so that they can create a conducive working environment to prevent fraud.

b. Standard preventative procedures. All employees in the organization make a written commitment as a key factor in preventing fraud.

c. Fraud detection procedures through automated systems such as the whistle-blowing system (WBS). The automated system includes reporting procedures for fraud founded and individuals involved in fraud.

\subsection{Impact of Internal Control in Fraud Prevention}

To prevent fraud, organizations strive to prevent fraud through changes in organizational behavior and culture to be able to give more attention to fraud [32]. Efforts made by organizations are through corporate governance structures, tone at the top, setting realistic goals, and policies and procedures that can prevent fraud [33]. Meanwhile, according to Albrecht fraud prevention can be done by creating a culture of honesty, openness and minimizing opportunities for fraud [25]. 
Fraud prevention is done as an effort to reduce fraud. The results of research conducted by Rozmita Dewi Yuniarti and Nelly Nur Apandi explained that the most effective fraud prevention must be returned to the morals and ethics of each party in the organization [32]. Fraud is carried out by ignoring internal controls [34]. Internal control is increasingly important in preventing fraud [34] but the role of internal control cannot completely prevent fraud [35] [17] so that internal control adapts performance methods and procedures that can correctly identify and interpret the likelihood of a fraud.

It is very important in fraud prevention by establishing an appropriate internal control system and separating the functions and responsibilities of work units appropriately [23]. Internal control as a means of analyzing data about fraud so that it can help to detect possible violations committed by individuals in the organization that may continue unnoticed by management. Moreover, decisive action against fraud perpetrators needs to be done. Thus, all employees in the organization understand the consequences of possible involvement in fraud and that the detection of fraud cannot be avoided thanks to an effective internal control system.

Effective internal control structure that is comprehensive by involving all people in the organization such as employees who are directly related to operational activities, the supervisory board, the board of directors, and the audit committee [36]. The impact of internal control is to ensure the quality of internal and external reports, ensure compliance with applicable laws. Regulations, and internal policies relating to business behavior, help to control operations through the authorization system, ensure that every records are kept accurately, the organization is able to respond rapidly to every business risks arising from factors in the organization and changes in the business environment, and ensure every weaknesses can be identified together so that corrective actions can be taken.

\section{Conclusion}

Strong internal control greatly influences fraud prevention. Weak internal control provides opportunities to commit fraud. Fraud will never be prevented completely, but public sector organizations can implement internal controls to prevent and detect fraud. Public sector organizations review the internal control system that has been running for example the system of authorizing financial transactions so as to prevent employees opportunities to commit fraud. Moreover, management in public sector organizations must be able to create anti-fraud awareness as an effort to prevent fraud. Public sector organizations can provide opportunities for employees to participate in training, seminars, and other activities regarding fraud prevention. Internal control as a means of analyzing fraud data, can help to detect possible violations committed by individuals in the public sector organization that may continue unnoticed by management. Furthermore, decisive action against fraud perpetrators needs to be done. Thus, all employees in the public sector organization understand the consequences of possible involvement in fraud and the detection of fraud cannot be avoided due to an effective internal control system. 


\section{References}

[1] C. Free, „Looking Through The Fraud Triangle: A Review and Call for New Directions,“ Meditary Accountancy Research Vol.23, pp. 175-196, 2015.

[2] ACFE Indonesia, „Survey Fraud Indonesia,“ ACFE Indonesia, Jakarta, 2016.

[3] ACFE Global, „Report To The Nation: 2018 Global Study On Occupational Fraud and Abuse,“ Association of Certified Fraud Examiners. Inc., Austin, 2018.

[4] M. Rahahleh, „The Impact of Multiple Authorities That Conduct Internal Control on Public Fund in The Control Process in Jorand," European Journal of Economics, Finance, and Administrative Sciences, zv. 28, pp. 44-60, 2011.

[5] J. S. Quah, „National Integrity Systems in East and Southeast Asia 2006 Regional Overview Report,“"Transparency International, Berlin, 2007.

[6] Organisation For Cooperation and Development (OECD), „Annual Report of European Central Bank in 2004: Glosary of Statistical Terms, “ United Nations Statistical Prevention and Detection, Paris, 2007.

[7] S. Chatterjee, Enron's Incremental Descent Into Bankruptcy: A Strategic and Organizational Analysis, Pergamon: Long Rang Planning, 2003.

[8] Nurhasanah, „Effectiveness of Internal Control, Internal Audit, Characteristic of The Institution and Corruption Cases (An Empirical Study in The Ministries/ Institutions,“ Journal of State Governance and Accountability, zv. 2, pp. 27-48, 2016.

[9] R. Simangunsong, ,The Impact of Internal Control Effectiveness and Internal Audit Role Toward the Performance of Local Government," Journal of FInance and Accounting, zv. 5, pp. 50-58, 2014.

[10] T. C. Cox a H. Wichman Jr., „The Perceived Quality of Internal Control System and Reports for State and Local Government,“ A Journal of Practice \& Theory, zv. 12, \%1. vyd.2, p. Fall, 1999.

[11] P. Richard, „,Report of The Chairman of The Board of Directors on Internal Control and Risk Management of Pernod Ricard in France," Journal of Corporate Governance and Internal Control, Zv. \%1 z \%2Reference Document 2008-2009`, \%1. vyd.Internal Control, pp. 15-34, 2009'.

[12] N. Chabrak a N. Daidj, „Enron: Widespread Myopia,“ Critical Perspective on Accounting, zv. 18, pp. 539-557, 2007.

[13] S. Srichunpech, „The Roles of Internal Auditors with Fraud in Organizations,“ Journal of Business Chulalongkorn Criticisms, zv. 104, \%1. vyd.2, pp. 48-59, 2005.

[14] Komisi Pemberantasan Korupsi, „Corruption Based on Institutions, “ Komisi Pemberantasan Korupsi, Jakarta, 2018.

[15] S. Green, Manager's Guide To The Sarbanes-Oxley Act: Improving Internal Controls To Prevent Fraud, New Jersey: John Wiley \& Sons. Inc, 2004.

[16] COSO, „Internal Control - Integrated Framework Executive Summary,“ American Institute of Certified Public Accountants, North Carolina, 2013.

[17] A. S. A. P. Salin, K. M. Zakaria a A. Nawawi, „Internal Control and Fraud - Empirical Evidence from Oil and Gas Company,“ Journal of Financial Crime, zv. 23`, \%1. vyd.4, pp. 1154-1168, 2016. 
[18] B. H. Purnomo, „The Role of Internal Audit in Governance, Risk, Management, and Control for Fraud Prevention at PPATK," Asia Pacific Fraud Journal, zv. 2, \%1. vyd.1, p. 20, 2017.

[19] G. Baldock, „The Perception of Corruption Across Europe, Middle East and Africa,“ Journal of Financial Crime, zv. 23, \%1. vyd.1, pp. 19-131, 2016.

[20] T. Gafarov a H. Hanusova, Autori, Financial Reporting Quality Control for Internal Control Implementation. [Performance]. Business and Management Faculty Institue of Finances BRNO University of Technology, 2009.

[21] INTOSAI, „Guidelines for Internal Control Standards for The Public Sector,“ INTOSAI General Secretariat - Rechnungshof, Vienna, 1992.

[22] M. B. Romney a P. J. Steinbart, Accounting Information System, USA: Cengage Learning, 2009.

[23] A. Petrascu a A. Tieanu, „The Role of Internal Audit in Fraud Prevention and Detection,“ rev. Procedia Economics and Finance, 2007.

[24] The Institute of Internal Auditors, „Fraud and Internal Audit,“ IIA Position Paper, Jakarta, 2019.

[25] S. Albrecht, C. C. Albrecht, C. O. Albrecht a M. F. Zimbelman, Fraud Examination, Mason Ohio: South-Western Cengage Learning, 2009.

[26] D. Coderre, Computer-AIded Fraud Prevention and Detection, New Jersey: John Wiley \& Sons. Inc., 2009.

[27] D. R. Cressey, Delinquency, Crime, and Differential Association, Netherlands: Martinus Nijhoff The Haque, 1964.

[28] M. Omar, A. Nawawi a A. S. A. P. Salin, „The Causes, Impact, and Prevention of Employee Fraud - A Case Study of An Automotive Company,“ Journal of Financial Crime, zv. 23, \%1. vyd.4, pp. 1012-1027, 2016.

[29] A. Schandi a P. L. Foster, COSO Internal Control Integrated Framework - An Implementation Guide For The Healthcare Provider Industry, Durham: Crowe, 2019.

[30] R. D. Yuniarti, „The Effect of Internal Control and Anti-Fraud Awareness on Fraud Prevention (A Survey on Inter-governmental Organizations),“ Journal of Economics Business and Accountancy Ventura, zv. 20, \%1. vyd.1, pp. 113-124, 2017.

[31] Badan Pengawasan Keuangan dan Pembangunan (BPKP), Fraud Auditing, Jakarta: Pusat Pendidikan dan Pelatihan Pengawasan BPKP, 2008.

[32] R. D. Yuniarti a N. N. Apandi, „Fraud Symptoms and The Role of Internal Auditors in Fraud Detection in Higher Education (Qualitative Study),“ Universitas Pendidikan Indonesia, Bandung, 2010.

[33] Singleton, Fraud Auditing and Forensic Accounting, New Jersey: John Wiley \& Sons, 2010.

[34] D. Caplan, „Internal Controls and The Detection of Management Fraud,“ Journal of Accounting Research, zv. 37, \%1. vyd.1, p. 114, 1999.

[35] V. Munteanu, M. Zuca a S. Zuca, Internal Audit in Public Companies and Institutions: Concept, Methodology, Regulations, and Case Studies, Bucharest: Wolter Kluwer, 2010.

[36] M. saleh, „Effect of Internal Control on Fraud Prevention in Maiduguri Manufacturing Industries Nigeria,“ rev. College of Business and Management Studies NIgeria, Borno State , 2017. 